\title{
Long-Term Forest Dynamics of Oromediterranean Fir Forests in Greece
}

\author{
Robert Brandes ${ }^{1 *}$, Anastasia Christopoulou ${ }^{2,3}$
}

(1) Geographer and independent consultant, Geuschmidstr. 8, D-90480 Nuernberg, Germany; (2) Nicolaus Copernicus University, Institute for the Study, Conservation and Restoration of Cultural Heritage, ul. Gagarina 11, PL-87-100 Toruń, Poland; (3) National and Kapodistrian University of Athens, Department of Biology, Section of Ecology and Systematics, Panepistimiopolis, GR-15784 Athens, Greece.

* Correspondence: e-mail: dr-robert-brandes@t-online.de
Citation: Brandes R, Christopoulou A, 2020. Long-Term Forest Dynamics of Oromediterranean Fir Forests in Greece. South-east Eur for 11 (1): 71-84. https:// doi.org/10.15177/seefor.20-02

Received: 7 Oct 2019; Revised: 19 Dec 2019; 28 Jan 2020; Accepted: 2 Feb 2020; Published online: 20 Mar 2020

\begin{abstract}
The present study illustrates the situation of the genus Abies in the Mediterranean and in Greece, focusing in detail on the oromediterranean forest of the southern Peloponnese, at Mt. Taygetos. The existing pattern of forest dynamics (mosaic cycle) and also the timberline dynamics are presented and explained. Since fir forests are highly susceptible to drought-related impacts (fire and fir dieback: insect outbreaks/ forest pathogens), the analysis of the present situation is put into perspective by looking at the role of direct human influence and the climatic fluctuations of the past, taking into consideration dendrochronological findings and archival climate records. In view of climate warming the question is whether in recent decades the fingerprints of climate change can already be observed in the Greek fir forests.

The study concludes that drought periods and climatic extremes have been an essential part of Greek climate for many centuries, causing high natural forest vulnerability. Therefore, fir dieback and fires are not a new phenomenon either - but in recent decades the accumulation of fuel, caused by land abandonment, has increased the danger of large wildfires. Nevertheless, the Greek mountain forests are highly endangered by increases in aridity and/or more frequent climate extremes (heat waves), together with increased risk of wildfires. Recommendations for an active forest management (counteracting expected adverse effects of climate change, by focusing on the establishment of an Abies cephalonica Loudon / Pinus nigra J. F. Arnold mosaic cycle) and further scientific research are provided.
\end{abstract}

Keywords: Greece; Abies sp.; Pinus nigra; timberline; dendrochronology; forest management

\section{INTRODUCTION}

The consequences of global warming on forest ecosystems and vegetation dynamics are an important ecological issue (Peters 1990, Lindner et al. 2010) that should be considered under adaptive forest management (Lindner et al. 2014, Yousefpour et al. 2017).

All Mediterranean Abies species grow in relatively moist and cool mountain areas, where they withdrew after the last ice age, forced by the increasingly dry and warm Mediterranean climate. The disjunction of their habitats caused the formation of various endemic species. Today, some of them (such as the fir species in northern Africa and A. pinsapo Boiss. in southern Spain) have already been reduced to small relict areas, while in the case of Abies nebrodensis (Lojac.) Mattei, on Sicily, actually only a few specimens have survived (Mayer 1985, Schütt 1994, Brandes and Ise 2007). Therefore, already 40 years ago, Quézel (1977) viewed the chances of survival for some of the Mediterranean Abies species with great skepticism.
Due to geographical isolation and the special climatic conditions, oromediterranean fir forests are restricted to mountain areas. Growing at its ecological boundary makes the genus particularly sensitive in regard to climate-ecological fluctuations or even profound climatic changes. For this reason Brandes and Ise (2007) identified the Abies forests as highly suitable study objects, in order to detect fingerprints of climate change (Walther 2001) in the vegetation of the Mediterranean. Global warming is most likely to exacerbate tree stress near the margins of the geographical or altitudinal species ranges, i.e. observations should be concentrated at ecological boundaries of zonal tree species (Delcourt and Delcourt 1992, Paine and Baker 1993).

Fire, as well as insect-outbreaks and pathogens, influence the health, the dynamics and the regeneration of Mediterranean fir forests. Several fir diebacks and wildfires were recorded in the last decades in the fir forests in Greece. But, are these processes already a consequence of a changing climate, or (still) part of natural climatic fluctuations, as they have existed for a 
long time? In order to assess this question, a broad scientific approach, considering many factors, is necessary.

The present study deals with the fir and pine/fir forests of the oromediterranean altitudinal zone (ca. 900-2000 m a.s.I.) on the Hellenic peninsula. They are of great ecological and economic importance, representing one of the most important forest types in Greece. Their existence depends on climateecological conditions differing from the lowlands by higher precipitation and lower temperatures (Efthimiou et al. 2014). Any climatic impacts changing these favorable hygric conditions would have negative ecological consequences on the mountain forests, especially in combination with land-use changes, leading to the accumulation of fuel for wildfires (Sarris et al. 2014). The aim of the current study is to give a synoptical, wide-angle view on the situation of the genus Abies in the Mediterranean and more precisely on the oromediterranean forests of the southern Peloponnese, at Mt. Taygetos, based on the results from earlier studies (Block and Brandes 2001, Brandes 2007, 2008, 2009, Brandes and Ise 2007). In addition, more recent ecological and forestry studies conducted after the 2007 wildfire were taken into account (Arianoutsou et al. 2010, Christopoulou et al. 2013, 2014, 2019, Sarris et al. 2014).

\section{Dominant Tree Species in the Oromediterranean Fo- rests of Greece}

In Greece, rather extended fir forests, estimated at almost 200000 ha (Aussenac 2002), still exist in the higher mountain areas, many of them under close-to-natural conditions. Three fir species are present on the Hellenic peninsula, namely Abies alba Mill., Abies borisii-regis Mattf. and Abies cephalonica Loudon, replacing each other from north to south, displaying an increasing drought-tolerance (Horvat et al. 1974, Brandes 2007, Korakis 2015, Mitsopoulos et al. 2015, Papadopoulos 2016). Abies alba reaches only the northernmost mountains (Rhodopi) at the Bulgarian border, seldom forming pure stands. The Balkan endemic Abies borisii-regis appears first in mixed forests (pines, fir and beeches) of Mt. Olympus and the northern Pindus (Smolikas, Tymphi), between ca. 900-1500 m a.s.l. Further south, this fir species forms huge, pure forests in the central and southern Pindus Mountains of Western Greece (Pertouli area, Tzoumerka, Tymphristos) between ca. $900 \mathrm{~m}$ a.s.l. and the treeline at ca. $1800 \mathrm{~m}$ altitude.

Greek fir (Abies cephalonica) is an endemic Greek species, appearing first in the high mountains of Central Greece (Vardoussia, Giona, Parnassos), often in mixed stands with A. borisii-regis. Due to intermediate morphological features, the two species are sometimes difficult to distinguish in this common distribution region (requiring a genetically-based differentiation) (Papadopoulos 2016). Eventually, in Southern Greece (i.e. mountains of the Peloponnese; Mt. Aenos/ island of Cephalonia; Mt. Parnitha in Attica; island of Euboea) $A$. cephalonica is the only existing fir species.

Pure fir forests, pure black pine (Pinus nigra J. F. Arnold) forests as well as mixed forests of fir and black pine are characteristic for the oromediterranean altitudinal zone of the Peloponnese (between ca. $900 \mathrm{~m}$ and the timberline at ca. 1900$2000 \mathrm{~m}$ a.s.l.). On extremely dry and rocky sites also Juniperus foetidissima Willd. can appear in the upper margin of the oromediterranean forests, forming the treeline in some areas of the Peloponnese (Erymanthos, Kyllini), in Central Greece (Giona) and also in the Pindus (Tymphi, Tzoumerka) (Brandes
2007, 2009). This reveals that for centuries some juniper-sites have obviously already been too dry for the establishment of $A$. cephalonica or P. nigra.

\section{The Oromediterranean Fir Forests Endangered by Cli- mate Change}

In recent decades, the oromediterranean forests of Greece have suffered not only from drought-related fir decline, but also from severe wildfires. The catastrophic fire year of 2007, destroying huge forest areas also in the mountains (e.g. at the National Park of Mt. Parnitha, near Athens, or at Mt. Taygetos on the Peloponnese) (Koutsias et al. 2012), caused the wellfounded concern that the mountain forests, i.e. ecosystems not adapted to high intensity crown fires, will be highly endangered by any future climate changes, which increases aridity (Arainoutsou et al. 2010, Christopoulou et al. 2013, 2014, 2018, Sarris et al. 2014).

Several climate studies predict for the $21^{\text {st }}$ century a warming trend in the Mediterranean basin, being associated with a decrease in summer precipitation and an increase in summer temperatures, as well as in the frequency of drought events and heat waves (Gao and Giorgi 2008, Giorgi and Lionello 2008, Fischer and Schar 2010, Diffenbaugh and Giorgi 2012, Nastos and Kapsomenakis 2015). This makes the area highly vulnerable to consequences of global change, including an increase of wildfires (Giannakopoulos et al. 2009, Dury et al. 2011, Lelieveld et al. 2012). In this context it must be stressed that the change of certain extreme values could already have an influence on vegetation - long before any climatic change becomes evident in climatic mean values (Walker 1991, Walther 2001).

\section{THE CASE STUDY OF MT TAYGETOS: CLIMATE, TREE SPECIES AND EXISTING FOREST PATTERN IN THE ORO- MEDITERRANEAN ZONE}

Mt. Taygetos (at ca. $36^{\circ} 57^{\prime} \mathrm{N} / 22^{\circ} 21^{\prime} \mathrm{E}$ ) is the highest (max. $2407 \mathrm{~m}$ a.s.l.) and longest mountain range on the Peloponnese and the southernmost on the Greek mainland (for location see Figure 1). Because of the immediate closeness to the Messenian Gulf the roughly north-south stretching mountain range is not the driest of the Peloponnese, though.

Climatologically Mt. Taygetos is an exemplary Mediterranean high mountain area. It underlies the characteristic Mediterranean summer incision in precipitation (causing intense dryness), a high full-year variability of precipitation and strong insolation.

Winters are cold, bringing frost and snow (>ca. $1000 \mathrm{~m}$ a.s.l.). Spring and autumn are characterized by higher precipitation and more cloud cover than in the lowlands (e.g. Bolle 2003). Based on data from a meteorological station situated at $1310 \mathrm{~m}$ a.s.l. mean annual precipitation is $983.4 \mathrm{~mm}$, but during the driest summer month (July) precipitation can be lower than $3 \mathrm{~mm}$. Only this special Mediterranean mountain climate renders the existence of the oromediterranean coniferous forests possible. Reliable, long-term climatic data from high elevations in Greece are missing, but Figure 2 gives an approximate idea about the oromediterranean climate (Artemisia is a Taygetos village at 750 $\mathrm{m}$ altitude, i.e. at the lower margin of the oromediterranean zone). 


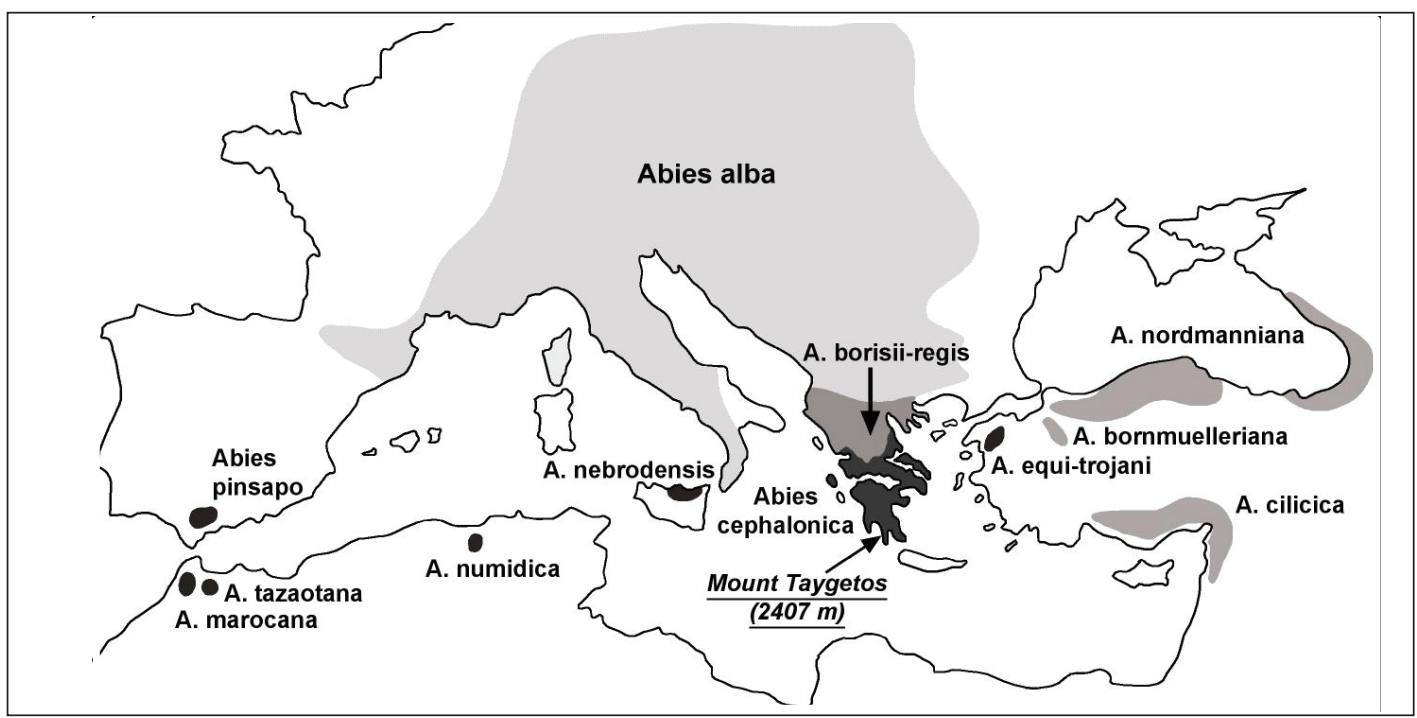

Figure 1. The study area (Mt. Taygetos, Greece) in regard to the circum-Mediterranean distribution of Abies species (from Brandes and Ise 2007, based on Schütt 1994).

Geologically, limestones (including dolomite and marble) prevail and often create rocky, dry soil conditions. In steep terrain this can impede the formation of dense forest cover. However, in flat or hollow areas with thick soil cover and in places where water-impermeable schist forms the bedrock, dense forests can grow.

The vegetation of the oromediterranean altitudinal zone is dominated by coniferous forest, which at Mt. Taygetos is formed by $A$. cephalonica and $P$. nigra, reaching from ca. $900 \mathrm{~m}$ a.s.l. to the timberline, at ca. 1800-1900(-2000) m a.s.l. (Brandes 2007). The two species differ from each other concerning their adaptation strategies and ecological behavior. Yet, exactly this makes them complementary in forest dynamics.

A. cephalonica is a shade-tolerant species and does not regenerate (well) on open sunny sites and on dry soils. Even though the Greek fir is a quite drought-resistant Abies species, it remains relatively demanding in regard to water supply, compared to black pine or juniper. Drought stress also explains why it is quite susceptible to pathogens (fungi, insects, mistletoe). In this regard it is no surprise that healthy $A$. cephalonica specimens of very old age ( $>200$ years) are hard to find on Mt. Taygetos.

Under fully natural conditions, wildfires are not a frequent event in the oromediterranean forests. If they were, the Greek fir could not be a characteristic tree of the mountain forests since it has no morphological adaptations against fire: the bark is thin, not providing insulation against extreme heat, and the branches reach far down on the stem (no self-pruning), facilitating crown fires. Accordingly, wildfires usually lead to the (almost) total destruction of fir stands. Natural post-fire recovery of fir is difficult, since the tree forms no serotinous cones, which could play a role as a canopy seed bank (Arianoutsou et al. 2010, Mitsopoulos et al. 2015, Christopoulou et al. 2018).

P. nigra, the other important tree of the mountain forest, is a typical pioneer species, invading successfully open, sunny

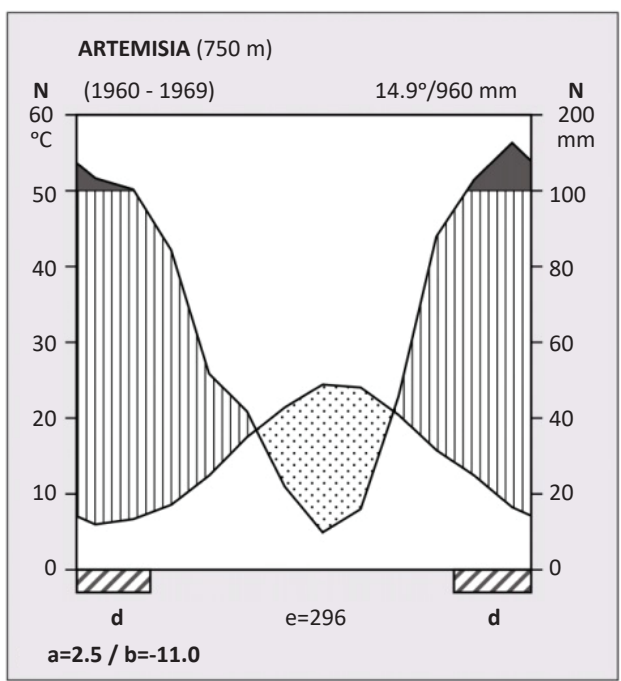

$\mathbf{a}=$ mean daily minimum of the coldest month $\left({ }^{\circ} \mathrm{C}\right)$

b $=$ absolute minimum $\left({ }^{\circ} \mathrm{C}\right)$

$\mathbf{d}=$ months with absolute minimum $<0{ }^{\circ} \mathrm{C}$

$\mathbf{e}=$ mean length of frost-free period (days)

Figure 2. Mediterranean mountain climate: diagram from Artemisia, Mt. Taygetos, ca. (750 m a.s.I.) (Brandes 2009).

and dry, even rocky sites - but it is almost unable to regenerate in the shade. Moreover, the heliophilous black pine is quite drought-resistant and shows little damage by pathogens (fungi, insects). Only mass outbreaks of Thaumetopoea pityocampa Schiff. (processionary moth), the most important insect pest in Greek pine forests, can lead to intense, but usually non-lethal 
defoliation of black pines (Avtzis 1983, Markalas 1987). The effect of processionary moth on black pine tree growth has been documented in several studies in the Mediterranean Basin, with the range of defoliation varying from 10 to $100 \%$ (Jacquet 2012). P. nigra has a very thick bark (up to $10-15 \mathrm{~cm}$ ) which protects the cambium from lethal heat damage and also allows older specimens to withstand low intensity surface fires (Tapias et al. 2004, Fulé et al. 2008, Christopoulou et al. 2013). Yet, like fir, black pine does not produce serotinous cones and does not maintain a canopy seed bank, so it cannot really be qualified as a typical pyrophyte (Christopoulou et al. 2013, 2014). Still, the overall excellent adaptation to its environment enables $P$. nigra to reach an age of 400-500 years and even more, making it very suitable for dendrochronological studies (Brandes 2007).

For both species it must be stressed that their seeds ripen in autumn. Thus, if a devastating forest fire strikes in summer (when most wildfires happen in Greece), there are no mature seeds to ensure regeneration. At least in large wildfires, i.e. fires that are larger than 500 ha (San-Miguel-Ayanz et al. 2013), this leads to an increased risk of non-potential re-establishment of the burned forest, due to regeneration failure (Ganatsas et al. 2012, Christopoulou et al. 2019).

The existing forest pattern at Mt. Taygetos constitutes a mosaic of distinct patches of different sizes, formed by pure stands of both species (of various age groups), and of various types of $A$. cephalonica/P. nigra mixed stands with different crown layers.

This type of oromediterranean coniferous forest, as we find it on Mt. Taygetos, exists also in the other mountain areas of the Peloponnese (Horvat et al. 1974, Brandes 2007). Therefore, conclusions from this contribution are not only meaningful for Mt. Taygetos, but for the whole Peloponnese, as well as for fir/ black pine forests in central and western Greece in general.

\section{Current Forest Dynamics and Its Drivers: Mosaic Cycle, Fire and Fir Dieback}

Various types of forest patches exist in the oromediterranean fir/black pine forest of Mt. Taygetos (Figure 3). Analyzing this pattern, it becomes obvious that the forest regenerates by means of an exemplary mosaic cycle, with fire being its main driving force (Pickett and White 1985, Block and Brandes 2001, Brandes 2007, Brandes and Ise 2007).

Black pine usually starts the forest recovery of open sites. Not only after fire, but also on abandoned field terraces, e.g. stone-built threshing floors (alonia in Greek), which are to be found under forest cover on the eastern side of the mountain at ca. $1300 \mathrm{~m}$ a.s.l. As the pines grow, forming stands with (semi-) shady conditions on the ground, the heliophilous $P$. nigra cannot regenerate anymore and $A$. cephalonica starts to invade the shady sites. Without disturbance, these patches will develop

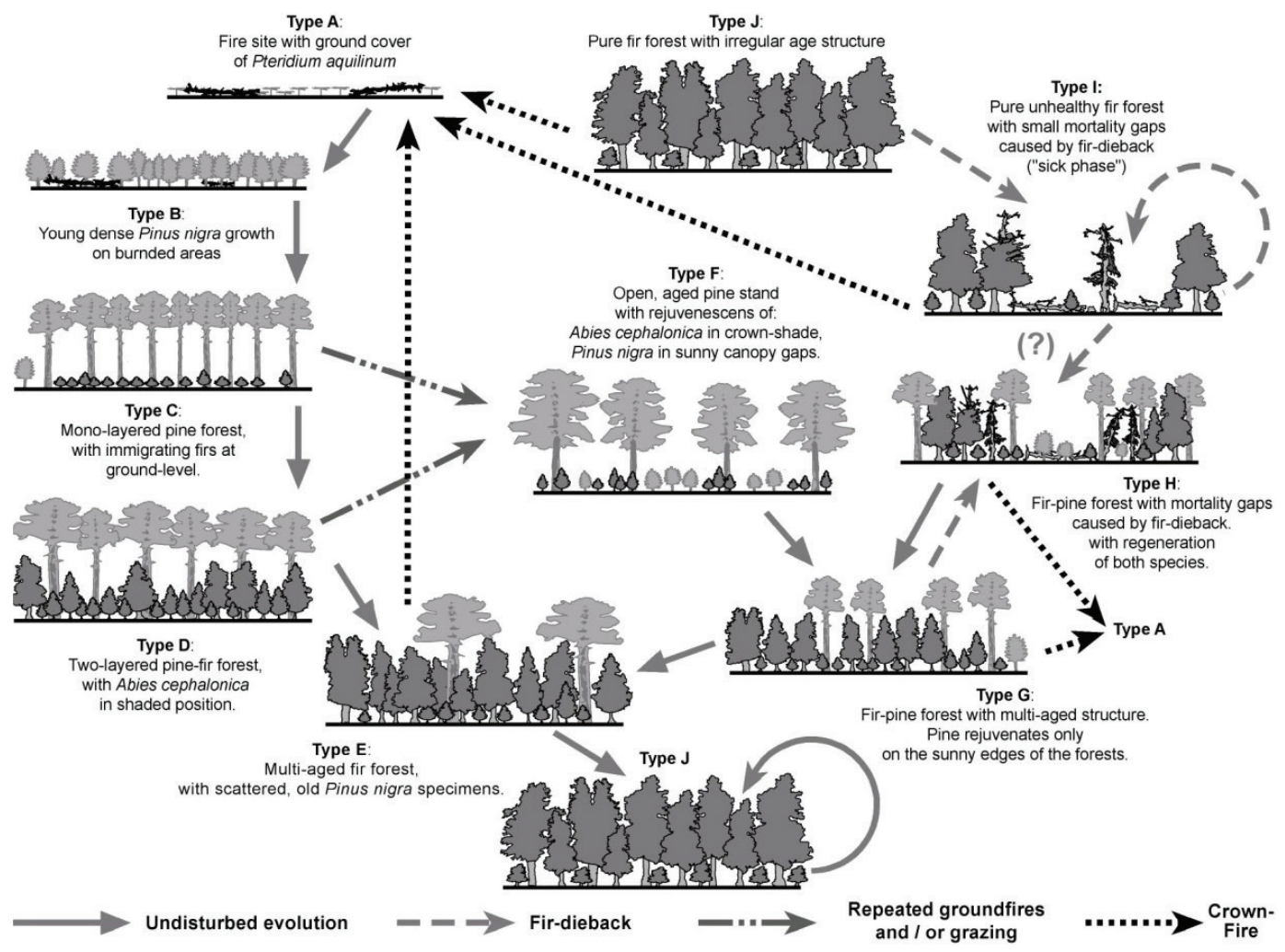

Figure 3. Fir/black pine mosaic cycle in the oromediterranean forest of Mt. Taygetos (from Brandes and Ise 2007, modified). 
into a fir forest with a few single old black pine specimens remaining. At the end of an undisturbed succession patches of pure, dense fir stands can be observed. These can fall into a socalled sick phase, caused by fir dieback.

It also becomes obvious that grazing and surface fires explain the shape of the patches, where $P$. nigra is growing to quite fire-resistant, old specimens in open stands (with little regeneration of Abies in the crown-shade and of black pine in the sunny spots). Dendrochronological research by Christopoulou et al. (2013) confirmed that low intensity surface fires, with mean fire intervals of ca. 30 years (8-103 years on single tree analysis), have been a common phenomenon at Mt. Taygetos for a long time, even during the $20^{\text {th }}$ century.

Fir dieback, the second driving force of the mosaic cycle, is a slow process caused by various factors (e.g. climate, air pollution, pathogenic fungi), out of which drought plays the key role. Indeed, a close temporal and causal connection between drought years and wide-spread fir dieback has been documented in fir stands of various regions in Greece for several years of the $20^{\text {th }}$ century and also in 2001 and 2002 (Markalas 1992, Brofas and Economidou 1994, Raftoyannis and Spanos 2015). The lack of water causes stress to the trees and thus favors the attack of various biotic factors. Figure 4 shows the complex process framework of the fir dieback (Brandes and Ise 2007).

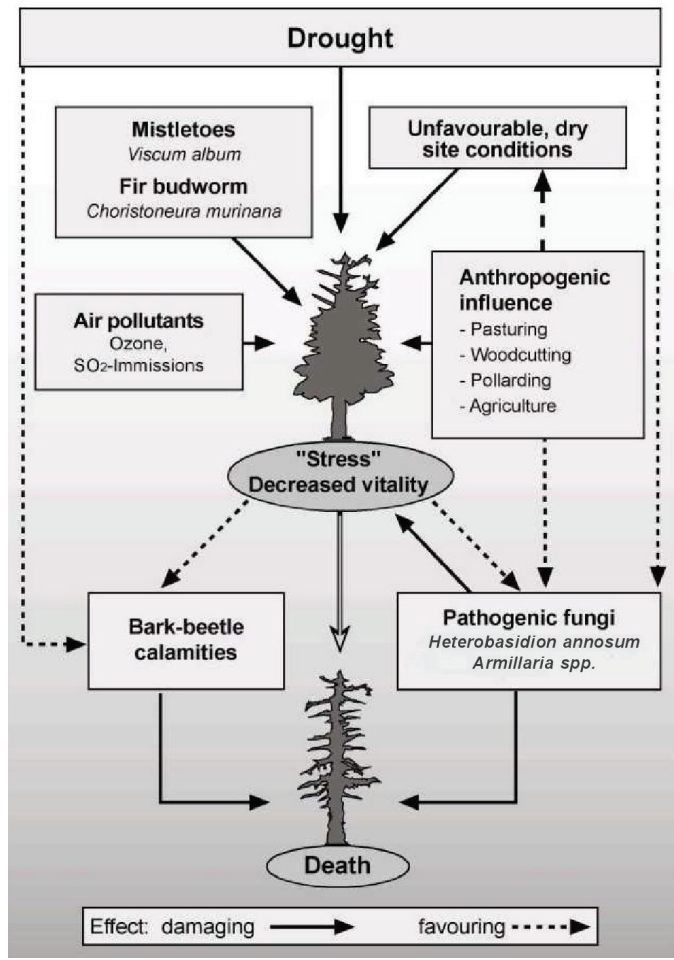

Figure 4. Process framework of fir dieback in Greek Abies forests (from Brandes and Ise 2007, modified).
Unfavorable site conditions (dry, rocky soils on limestones) can easily lead to stress, if there is a lack of rainfall. On dry sites plants usually develop higher root-to-shoot ratios in order to secure access to water (Brunner et al. 2015). Nevertheless, in some cases, especially on rocky sites, the root system cannot grow enough anymore in order to sustain the above-ground parts of a tall tree and to supply it with water and nutrients. In this case the tree starts to die from the top, which sometimes leads to so-called spike top growth forms (Fritts 1976, Brandes 2007).

Anthropogenic influences such as air pollution (Larsen et al. 1990, Lelieveld et al. 2002) and grazing have contributed in various ways to the fir forests damage (e.g. mechanical damages to trees, site deterioration, spreading of pathogenic fungi). Fir budworm (Choristoneura murinana) and mistletoe (Viscum album) are also species that can cause damages to Abies in Greece (Sinclair et al. 1987, Barbu 2010, Tsopelas et al. 2004, Ganatsas et al. 2012, Smidla et al. 2019).

The stress caused by the already mentioned factors greatly facilitates a successful attack by pathogenic fungi. Only Armillaria species kill single firs rather quickly. The more widely spread fungus in the Greek fir forests is root rot (Heterobasidion annosum). By slowly destroying the root system of a tree, it leads to difficulties in water uptake and dieback of the crown. Therefore this fungus strongly contributes to the widespread phenomenon of unhealthy looking firs, being in a sick-phase which can last for many years or even decades (Tsopelas and Korhonen 1996, Tsopelas 1999). Numerous fir individuals within the forest of Taygetos are in a poor state of health. The same can be observed in other mountain forests of the Peloponnese, as well as in Central Greece and the Pindus Mountains (Brandes 2007).

Eventually, the outbreak of bark beetle is also very closely connected with drought years, mainly if the rainfall deficit occurs in spring and early summer. The insects profit from the weakened defense mechanism of the stressed Abies trees and also from higher temperatures during periods of drought. Episodic bark beetle calamities, on regional or even nation-wide scale, have been documented by the Greek forests authorities since 1929 (Kailidis and Markalas 1988). The last intense and nation-wide bark beetle outbreak, with losses of up to $40 \%$ of the trees in certain regions, happened between 1987 and 1990 and was connected to the drought period of 1986-1990 (Markalas 1992).

Fir dieback leads to the slow decay of single trees, but also to distinct small mortality gaps inside the dense forest (Brandes 2007, Brandes and Ise 2007). Especially the selective dying of firs in mixed stands with black pine clearly points out that pathogenic fungi (which only rarely do any damage to $P$. nigra) are an important factor in the process framework of fir dieback. Since in southern Greece the mortality gaps are rather small (max. diameter ca. $100 \mathrm{~m}$ ), they get closed again by the establishment of black pines or even firs.

\section{Timberline Dynamics}

A study of 11 high mountain areas of Greece revealed that the ecology of timberlines in Greece is not only influenced by the climatic conditions of winter (snow, frost), but also by the complex dryness, which corresponds to rocky, dry sites; high insolation, dry summers and drought events. The 
complex dryness plays a limiting role, influencing the health of established trees and of seedling establishment / tree regeneration (Brandes 2007).

The dieback of firs is the most important dynamic process at the timberline. In some areas, among them Mt. Taygetos, the decay of fir stands has already led to a local treeline decline of 50-200 $\mathrm{m}$ of altitude. At the upper margin of the timberline ecotone, where rocky, dry sites prevail, the slow dying of older firs is accompanied by a general insufficiency or even total lack of regeneration. Only at the lower part of the timberline ecotone, in flat or hollow landforms, with deeper soils and snow/moisture accumulation, the rejuvenation of firs and black pines, caused by the reduction of grazing, can be vigorous. Often former, sometimes even terraced pasture grounds and fields are reconquered by young dense tree stands. Figure 5 and 6 illustrate the situation at Mt Taygetos.

The important role of the ecological complex dryness at the timberlines in southern and central Greece is confirmed by contrasting treeline observations in Albania, Montenegro, Spain and Italy. There, a high altitude tree densification or even a locally starting treeline advance has been documented (Vitali et al. 2019). This recent process, synchronic at all sites (last 30 years), is mainly a consequence of reduced grazing, with still unclear role of the climate. Even though the sites examined by Vitali et al. (2019) belong culturally (transhumant land use) and geographically to the Mediterranean world, heat and summer drought are not major limiting ecological factors in them. This becomes clear by looking at the ecological profiles and the geographical distribution of the tree species forming the timberlines: $P$. heldreichii, $P$. peuce, $P$. sylvestris and $P$. uncinata. The last one does not exist in southeastern Europe at all, so it cannot be compared. But $P$. peuce and $P$. sylvestris are only to be found in the very north of Greece (Rhodopi mountains), i.e. in areas without intense summer drought. $P$. heldreichii reaches its southern geographical limit at ca. $40^{\circ}$ latitude, on Monte Pollino in Italy and in Greece on Mt. Olympus and in the northern Pindus (north face of Tymphi, Smolikas), also forming the treeline. Further south, the climate-ecological situation, even at high altitudes, becomes too dry for Bosnian pine (Brandes and Ise 2007).

The regressive timberline dynamics, caused by fir dieback and lack of fir regeneration, make it obvious that in recent decades the climatic situation for the survival and the rejuvenation of fir at the timberline ecotone has been unfavorable. Human impact (mainly by grazing of sheep and goats) cannot explain these dynamics, because it has been strongly reduced since the second half of the $20^{\text {th }}$ century. Today, fir stands are disintegrating and slowly disappearing, which had grown in times of higher population in the mountain villages - and therefore in times of much stronger grazing impact (ca. 1750-1950 AD), but probably of more favourable climatic conditions for rejuvenation. Since $A$. cephalonica (similar to $P$. nigra) depends very much on precipitation in late spring and summer (Papadopoulos 2016, Fyllas et al. 2017), it may be concluded that single severe drought years and longer periods of sub-normal rainfall conditions, as revealed by tree-ring chronologies from Pinus nigra at Mt. Taygetos (Brandes 2007), also determine the conditions for survival and regeneration of Abies, especially at the timberline ecotone. At this ecological boundary the winter climate conditions are an additional aspect, reducing the number of climatically favourable years even more. All together it is hard to assess, which factors exactly are decisive in impeding regeneration. For sure it can only be said that climatic influences, i.e. a series of favourable years (in winter and summer climate), obviously play a decisive role in successful tree seedling establishment in the ecotone. It is remarkable that the treeline in Greece does not advance in altitude, which is caused by reduced grazing and/or warmer temperatures. It seems that in recent decades the ecological complex of dryness stands against a treeline advance, as it is documented in climatically wetter mountains on the Balkans and as it is generally expected for many treelines in other parts of the world (Holtmeier 2003, Vitali et al. 2019).

\section{Climatic Fluctuations and Their Effects on Forest Dyna- mics in the Past}

Since drought years play a central role in fir dieback and wildfires, it is of special interest to ask if these events are a new phenomenon of the $20^{\text {th }}$ and $21^{\text {st }}$ century, related to global warming - or if they occurred in the past as well?

The limited information capacity of meteorological data (records in Greece start only since the end of the $19^{\text {th }}$ century) makes it necessary to switch to methods of dendrochronology, combined with information from historical sources (Sarris et al. 2014). Both yield proxy data of climate from the past (Glaser et al. 2000).

\section{Climatic Information from Dendrochronology}

Dendrochronological research carried out on P. nigra in Mt. Taygetos (sampled on 1400-1700 m a.s.l.) provided the data for tree-ring width chronologies of this area (Brandes 2007, 2009). Figure 7 shows a 472 years chronology going back to 1538 AD, together with a 10-year low-pass filter. The figure was made by $\mathrm{R}$ using the dplr package (Bunn et al. 2019). Statistically revealed climate-growth relations indicated that the precipitation during the growing season (first of all in May/June) has the strongest influence on the tree-ring width of black pines of Taygetos (Brandes 2007, 2009). Similarly, Fyllas et al. (2017) found that the growth of both A. cephalonica and P. nigra at Mt. Taygetos was positively correlated with May precipitation.

The periods of suppressed growth in the low-pass filtered chronology may be interpreted, under simplifying assumptions, as relatively dry phases, mainly concerning spring and early summer precipitation (and vice versa).

As a whole the dendrochronological results from Mt. Taygetos prove the occurrence of marked long-term cyclic fluctuations in precipitation, superimposed by high interannual rainfall variability, a characteristic feature of the Mediterranean climate. Hence the drought years at the end of the $20^{\text {th }}$ century are to be seen as part of an intense and long-lasting climatically unfavourable dry period. Nevertheless, set into a view of the total this period is not at all to be classified as exceptional.

These dendroclimatological results from Mt. Taygetos fit into the general picture drawn by other tree-ring analyses from the eastern Mediterranean (Waldner and Schweingruber 1996, Hughes et al. 2001, Papadopoulos 2016, Klippel et al. 2018).

\section{Climatic Information from Historical Archives}

Historical sources are well suited for the verification of dendroclimatological findings (as demonstrated, e.g. Richter and Eckstein 1990) and yield valuable information on their own. By evaluating Venetian archives, Grove and Conterio (1995) made it evident for Crete (ca. $200 \mathrm{~km}$ south of Mt. Taygetos) that in some years of the $16^{\text {th }}$ and $17^{\text {th }}$ centuries severe winters 


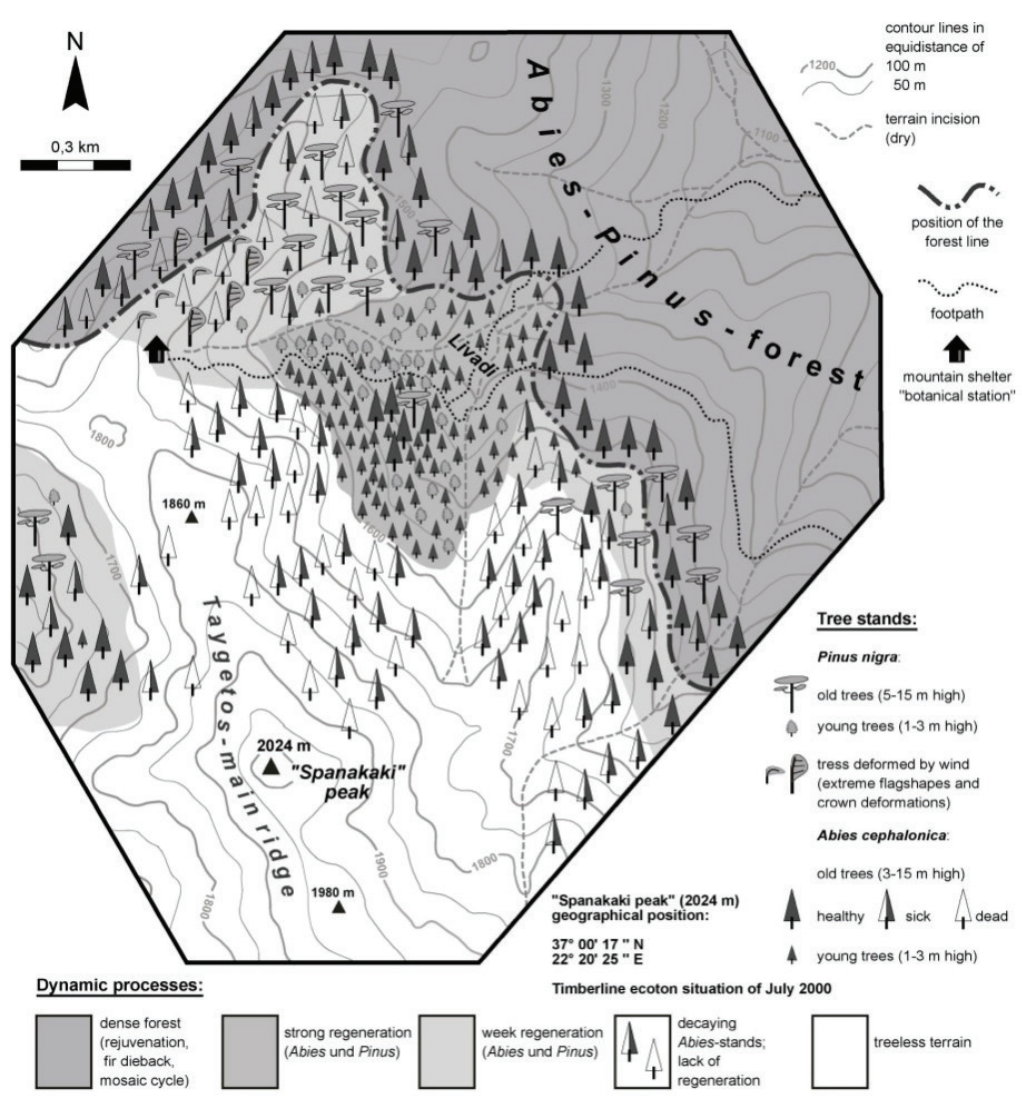

Figure 5. Exemplary situation of dynamics at the timberline ecotone, near Spanakaki peak (2024 m a.s.l.) on the eastern side of Mt. Taygetos, situation of July 2000. Based on Brandes (2007), modified.

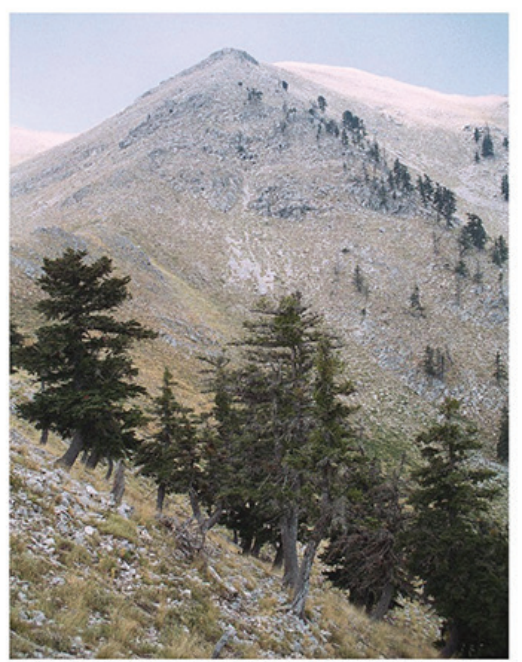

(a)

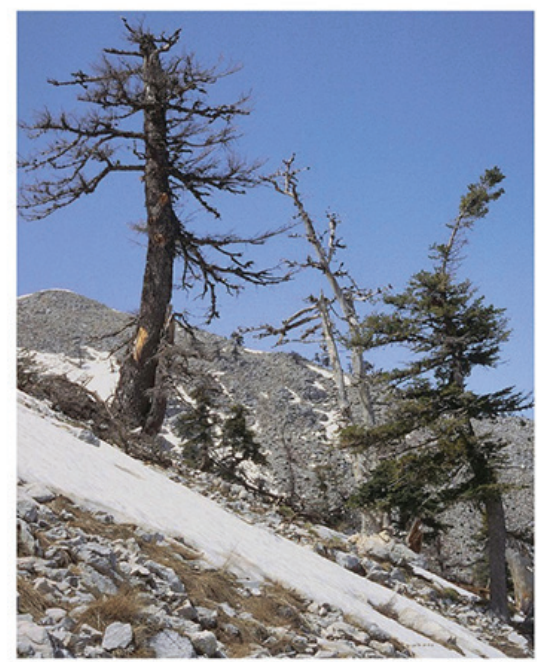

(b)

Figure 6. Lack of regeneration and fir dieback, NE of Spanakaki peak, Mt. Taygetos, ca. 1700-1800 m a.s.I., situation of July 2000 (a) and April 2000 (b). 


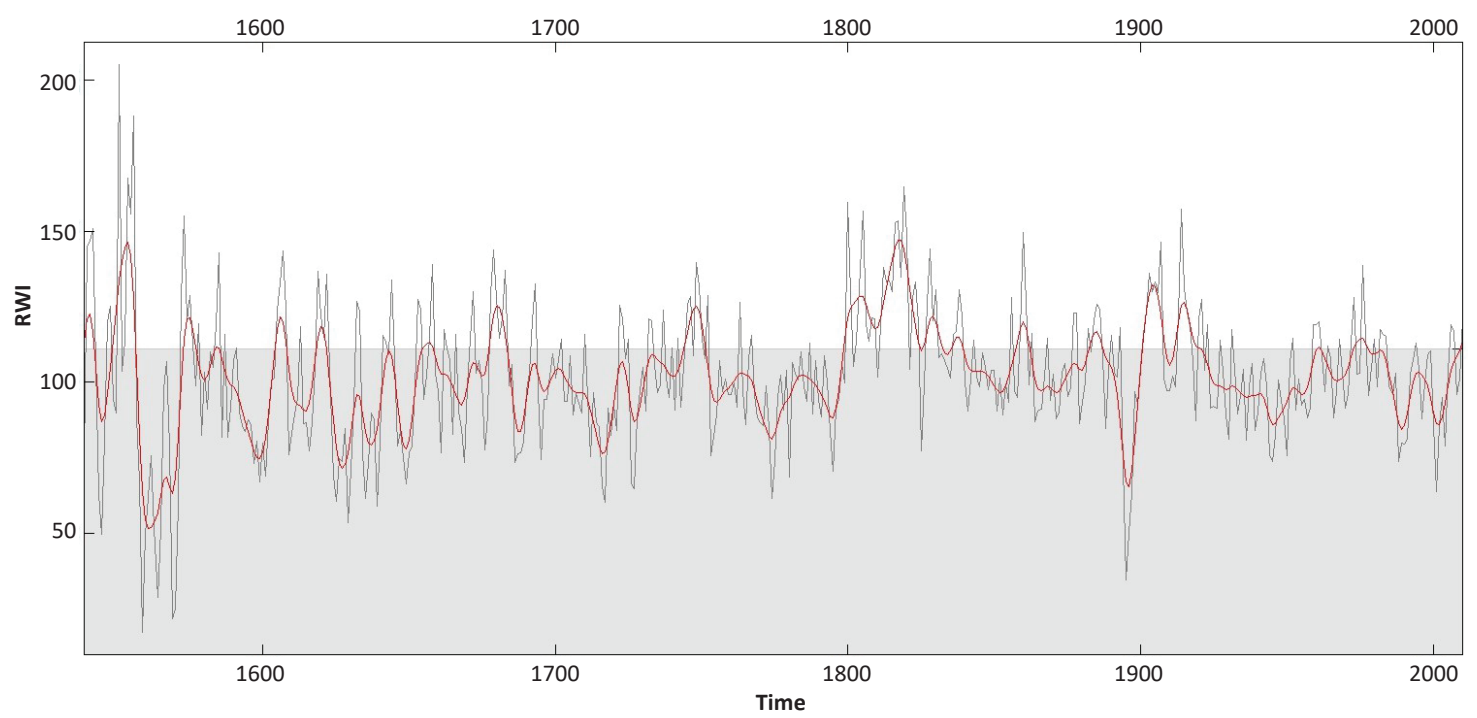

Figure 7. Year ring chronology from Pinus nigra, Mt. Taygetos, 1538-2010 AD, smoothed by a 10-year low-pass filter. Small sample replication (8 trees) contributes to strong oscillation amplitudes before the year 1640 .

and heavy summer rains, unusually intense compared to $20^{\text {th }}$ century standards, occurred there. Concerning the periods of drought, the authors even state that none of the $20^{\text {th }}$ century drought years have experienced such long rainless periods as those in the period 1547-1645 AD, nor such a complete lack of winter rain.

Another example is 1715 AD, according to Xoplaki et al. (2001) a year of great famine in central and southern Greece, following dryness all over the country from November 1712 to summer 1714 . In 1873/74 thousands of people and animals died of starvation in Turkey. According to Kuniholm (1990), tree-ring chronologies from all over the Aegean show subnormal growth for 1873 and 1874, following four other years of significantly subnormal growth. The Taygetos chronologies too identify 1861-1874 as a period of unfavourable rainfall conditions. These examples, and also other well-known drought events in the Aegean region, are mirrored in the tree-ring chronologies from Taygetos, showing years/periods of weak tree growth (Kuniholm 1990, Grove and Grove 1992, Brandes 2007).

In general, information from dendrochronology, historical archives and archaeology clearly affirms that for millennia drought years, as well as decennial and centennial precipitation fluctuations, were essential parts in the spectrum of natural climatic variability in the Aegean. Obviously no lasting climatic changes have happened in this region since the last sub-pluvial (2000-3000 BC). This relative constancy of climate also manifests itself in the good agreement between ancient descriptions and today's plant cover and wind trajectories (Lamb 1977, Thirgood 1981, Hempel 1990, 2000, Kuniholm 1990).

Based on dendrochronological and historical information, it may be concluded that for hundreds of years drought events and drought periods have been an integral part of Greek climate. Therefore, it must be assumed that seasonal water deficits would always have had negative influences on the physical condition of Abies on the Hellenic peninsula. And indeed, indications of this have been found even in statements from antiquity. Theophrast (370-285 BC) and Plinius (first century AD) say that the best timber used in Greece came from the geographical region of Macedonia, in northern Greece (Rhodopi mountains, Chalkidiki) and the Turkish black-sea coast, the worst from Parnassos, Euboea and Arcadia. There is a good reason to assume that they were referring to Abies wood, since in antiquity firs were the most important timber for the making of ships, as well as for the construction of buildings (cf. Meiggs 1982). It would fit perfectly into the ecological picture that $A$. alba from the Rhodopi mountains or $A$. bornmuelleriana and $A$. nordmanniana from the wet slopes of the Pontic mountains had delivered superior quality wood, compared to $A$. cephalonica-trunks (from Parnassos, Euboea, Arcadia). In Central and Southern Greece, where summer dryness and episodic drought events are typical characteristics of climate, bark beetle epidemics and pathogenic fungi, easily spread by human activities in forests well above their natural rate, probably have always played a major role in making the wood of relatively tall old firs technically quite useless (rot inside the trunks caused by fungi), exactly like today.

This consideration is confirmed by the example of Parnes (today Parnitha National Park), a mountain of $1413 \mathrm{~m}$ altitude, only $20 \mathrm{~km}$ north of the Greek capital. During the $5^{\text {th }}$ century $B C$, when Athens already depended on timber imports from northern Greece in order to realize huge building programs, the timber resources of mount Parnes were not drawn upon. The import by sea was probably preferred not only because of transport difficulties by land (which would have required huge wagon-building programs first), but also because of the firs' poor timber quality (Meiggs 1982).

In the further course of antiquity not even charcoal works seemed to have caused a total destruction of the forest on mount Parnes. This can be concluded from the fact that the area was used for hunting bears and wild boar during the times of Pausanias (late $2^{\text {nd }}$ century AD; Meiggs 1982). Reports from the 
early $19^{\text {th }}$ century even spoke of inexhaustible supply of timber there (McNeill 1992). Extended fir forests covered the mountain even during the $20^{\text {th }}$ century. Nevertheless, almost $50 \%$ of the fir forest was burned during the 2007 wildfire and even 10 years after the fire $A$. cephalonica recruitment remains rather poor (Christopoulou et al. 2018).

\section{Assessing the Role of Direct and Indirect Human Influ- ences on Forest Dynamics}

Based on the above-mentioned, periods of drought, fir dieback or bark beetle epidemics in the forests of Greece should not be readily interpreted as a per se new (i.e. climate change related) phenomenon. Moreover, the direct and indirect human influences, affecting the health of fir stands in Greece in a negative way, should also be taken into account. First of all it must be highly considered that the period of ca. 1750-1950 AD was a time of relative overpopulation in the mountain villages of Greece, which means it was the absolute historical peak period of direct human impact on the mountain forests (McNeill 1992, Brandes 2007). Since the middle of the $20^{\text {th }}$ century sometimes total depopulation of the mountain villages took place, together with land abandonment. Therefore, all recent processes in the Greek oromediterranean forests must always be viewed against the background of former land use.

Direct human impact on the oromediterranean forest consisted mainly in grazing (forest pasture of sheep and goats), which did restrain regeneration, leading sometimes to an overageing of stands in the forest and especially at the timberline. Systematic timber-cutting (lumbering for timber or fire-wood, charcoal working and even opening small fields for grain and corn farming up to $1300 \mathrm{~m}$ a.s.l.) remained restricted to those parts of the terrain which also allowed a profitable removal of the wood. In the pathless mountain regions this meant that many fir forests were spared the axe because of their remote location and their inaccessibility for wheels. On the Hellenic peninsula most forest roads and even many road connections between mountain villages had not been built before the second half of the $20^{\text {th }}$ century, often only after ca. 1970 . Anthropogenous fires contributed to an impairment of the natural forests as well; at least they lead to a considerable increase in the frequency of (low intensity) ground fires, keeping available fuel low.

In some places these direct anthropogenic influences resulted in erosion and site-degradation. But even where this was not the case and the Abies forest has fully recuperated (partly involving a temporary species change with $P$. nigra as pioneer on open sites), former timber cutting as well as grazing had a long-term effect which is not very widely known: the spread of pathogenic fungi, above all Heterobasidion annosum and Armillaria spp.

Since these pathogens damage the root system, they increase the susceptibility of the trees to climatically caused hygric stress. Once airborne basidiospores of the fungi have infected stumps or wounds at the base of the stem, the infections colonize the root system and spread also to healthy trees via root contacts. The significance of pathogenic fungi for today's poor physical condition of Mediterranean fir forests must not be underestimated because they form a permanent disease which is very hard to eliminate from once infested stands (Harrington 1993, Tsopelas and Korhonen 1996, Woodward et al. 1998, Tsopelas 1999).
Since the $20^{\text {th }}$ century has been an additional non-climatic factor related to human activities: air pollution. Even though Greece is not heavily industrialized, nevertheless air pollution is an important factor there because of emissions from Western and Eastern Europe drifting into the Eastern Mediterranean. Thus even in Crete ozone-values can reach the amount which is $10-15 \%$ above the usual levels for Central Europe (Lelieveld et al. 2002). Detailed research for the assessment of the 03impact on Greek forests has yet to come, though. Experiments by Larsen et al. (1990) on Abies alba give an indication of the adverse effects on firs. They yielded the result that ozone fumigation causes a reduction in photosynthesis and the rate of transpiration, but a strong increase in the rate of respiration. Moreover, frost hardiness is reduced, shoot is retarded and the increment in height and diameter is reduced.

In combination with very dry weather conditions (drying out normally rather moist dead wood) even in the mountain forests devastating fires can occur (Mitsopoulos et al. 2015). However, the factor of fire is also closely connected to human action. The high mountains of Greece are embedded into a cultural landscape, which has been populated for thousands of years - and the reduction of human influence (grazing, woodcutting) since ca. 1950, as well as many years of fire exclusion, have led to an accumulation of fuel in the mountain forests in the last decades (dead wood remaining in the forests; denser tree stands by natural rejuvenation). In the northwestern part of Mt. Taygetos, for example, the longest fire-free period lasted 34 years, from 1973 until high severity crown fire in 2007 (Christopoulou et al. 2013). This development has also lead to more pure stands of Greek fir, dominating many forests today, and increasing the likelihood of large fires (Sarris et al. 2014, Raftoyannis and Spanos 2015).

Most fires occurring in Greece are caused by humans, often by arson. For the period $1983-2008$ only about $4.1 \%$ of all fires in Greece originated from lightning (Tsagari et al. 2011).

Therefore, there is no doubt that heat waves and general lack of rain heavily increase the risk of wildfires in the oromediterranean forests - but without the spark being caused by humans, it remains doubtful how often wildfires would originate if they were restricted to purely natural ignition (lightning). Against the proven historical background of dry weather periods being a fully normal feature of the Greek climate, we must be careful to interpret extreme fire-years, like the last one in 2007, mainly as a consequence of climate warming. Interestingly, in the last 12 years no major fires have occurred in the mountain forests of Greece.

\section{The Importance of the Mosaic Cycle under Climate Change Conditions}

The unusually severe and devastating wildfires of the year 2007 destroyed huge forest areas of the oromediterranean altitudinal zone, formed by $A$. cephalonica and/or $P$. nigra. Especially at the National Park of Mt. Parnitha and in the northwestern part of Mt. Taygetos a few thousand hectares of fir and black pine forest burned down (Arianoutsou et al. 2010). At Taygetos, some of these areas had already been affected by fire in 1998 (Christopoulou et al. 2013). Several studies have monitored the process of natural regeneration and of active reforestation in these two prominent areas (Ganatsas et al. 2012, Christopoulou et al. 2014, 2018, 2019, Efthimiou et al. 2014, Siorokou et al. 2015). 
The probably most important finding of these studies is that natural regeneration of both fir and black pine depends first of all on the distance to unburned forest patches, corresponding to the anemochorous seed dispersal of the two species (Ganatsas et al. 2012, Christopoulou et al. 2014, 2018). Therefore, the survival of mature and tall trees plays a paramount role in supplying seeds and shade for the establishment of seedlings.

It also became clear that forest patches, which had been burned twice within a few years at Mt. Taygetos, showed extremely low regeneration (Christopoulou et al. 2014). Of course, a number of biotic and abiotic factors (vegetation cover, soil conditions, competition, seed predation by animals, insolation, climatic conditions in the first years following a fire) also mediate the recruitment of young trees. In microhabitats formed by coarse woody debris (trunks, dead branches etc. covering the soil), where seedlings and saplings are better protected from high temperatures and excessive water loss, regeneration density proved to be higher (Christopoulou et al. 2014, 2018), a fact that does not support the widespread praxis of Greek forestry to remove dead trees after a fire.

Even 10 years after the fires, natural regeneration in the former A. cephalonica forests of Mt. Parnitha and Mt. Taygetos was still quite poor. The low levels of regeneration can be mainly attributed to the ecological characteristics of the tree species in combination with the unfavorable, i.e. dry, site conditions in the post-fire environment. The poor recruitment density, especially on sites of formerly pure Abies stands, makes it questionable if natural processes alone can ensure the full recovery of the forest. At least on dry sites this seems rather unlikely. Only on sites with favorable conditions, i.e. high rainfall and deep soils (as in Central Greece), a natural regeneration of fir forests is expected to happen within ca. 50 years after a fire (Raftoyannis and Spanos 2015).

If regeneration fails, there is a high risk that former forest sites might turn into open mesoxerophytic grassland, phrygana dominated by Genista acanthoclada, Sarcopoterium spinosum and Thymbra capitata or into areas densely covered by Pteridium aquilinum (Christopoulou et al. 2019). This has led to efforts of active reforestation. Planting seedlings is very difficult and costly. It requires careful planning, but often yields very poor results. Moreover, seedling establishment and survival of young Greek firs in time is better accomplished in the protective shade offered by elder plants (Politi et al. 2009). Therefore, at the southern exposures and drier sites of Parnitha, Pinus nigra (promising to be more drought- and heat-tolerant than fir) was planted with the aim of Abies to return later, under the canopy of black pines. However, the survival rate of the pine seedlings hardly reached $50 \%$, not fulfilling the expectations (Siorokou et al. 2015).

The above considerations make it clear that devastating wildfires are the most serious threat to the oromediterranean forests. This is based on fuel accumulation by land abandonment, combined with drought intensification projected for the Mediterranean region under global warming (Sarris et al. 2014).

Fire suppression and reforestation are difficult steps with highly uncertain results. Therefore, the focus of forest protection must be directed towards fire prevention and active management of the forest structures wherever the terrain is accessible.

A survey by Greek forest experts revealed restrictions in climate change forest management, caused by budget and staff constraints, as well as by the need for the establishment of a new firefighting organization and for the better coordination of all involved parties during fire suppression (Mitsopoulos et al. 2015). Against the background of the discussion about $\mathrm{CO}_{2}$ emissions and $\mathrm{CO}_{2}$ sinks, it should be a priority task of national and European authorities to allocate sufficient financial resources and manpower to the Greek foresters. According to the same study, Greek forest experts say that fire prevention in fir forests under climate change should be focused on public awareness and fuel management.

The expected rapidity of climate change makes unmanaged natural ecosystems probably more endangered than managed ecosystems (Gates 1993). Therefore, the results of the present study suggest that forestry measures should not only aim at an improved fuel management, but also at the active establishment of an A. cephalonica/P. nigra mosaic cycle, as presented in Figure 3. Under optimal conditions, the size of the patches should be aligned with the structures of topography. In relatively flat terrain, fire aisles should form the borders of the patches. Since the risk of fires in the mountain forests will increase with climate change, it is most important to avoid that the fires reach catastrophic size and lead to a total forest destruction on a large scale, making forest regeneration difficult or even impossible.

Yet, on a small scale and of low intensity, fires can even help to establish the mosaic cycle more easily than it is achieved only by mechanical stand thinning. The legislation in Greece does not allow the use of prescribed burning in forest management, although it could possibly provide an important tool to forest managers. Where pure fir stands form huge forests, $P$. nigra islands could be planted to create a start for the establishment of a future mosaic cycle.

Where mixed fir/black pine or pure pine forests already exist, the creation of stand types corresponding to type $\mathrm{F}$ in Figure 3 should have the highest priority. The study by Christopoulou et al. (2013) confirmed that stands with large P. nigra trees having a very thick bark are most likely to survive low intensity surface fires, and therefore they are decisive for natural postfire regeneration of the forest (Christopoulou et al. 2014). Thus, the authors saw it as an important forest management issue to maintain fire resistant stands through appropriate understory fuel treatment (by stand thinning, selective understory removal, moderate grazing and even prescribed burning). In the event of a wildfire this will lead only to low intensity or patchy burning.

At Mt. Taygetos an exemplary mosaic cycle of relative small patches exists on the eastern flank of the mountain. In contrast, in the northwestern part of Taygetos, where topography is much less structured, fires destroyed huge, relatively homogenous forest areas which will need a very long time to recover, if they will recover at all. From this situation the following conclusions can be drawn:

The mosaic cycle of $P$. nigra and $A$. cephalonica makes the ecosystem of the oromediterranean forest at Mt. Taygetos relatively resistant to the impacts of fire and fir dieback. The disturbances in the various single patches give a greater stability to the forest as a whole, compared to pure Abies forests (Block and Brandes 2001, Brandes 2007, Brandes and Ise 2007).

As long as forest fires do not surpass a certain fire interval and as long as the burned surface is not too big, the disturbance fire creates patches of different, asynchronous stages of forest succession in which a change of the key species, $A$. cephalonica and $P$. nigra, takes place. This patchwork makes the ecosystem as a whole very stable. As it is typical for many mosaic cycles, at Taygetos it can also be seen that the forest ecosystem exists and 
evolves under the headline stability by disturbance (Pickett and White 1985, Remmert 1991, Block and Brandes 2001). For many centuries the forest has adapted to frequent, but low-intensity surface fires (mainly caused by humans). Thus, neither wildfires per se nor the fir dieback will put the existence of the fir/pine forest at risk - as long as these disturbances do not surpass a certain scale or frequency. Since climate change will lead to devastating and more frequent fires, active forest management is necessary in order to counteract this risk.

\section{CONCLUSIONS}

The oromediterranean forests of Greece, particularly where formed purely by Abies, are not (well) adapted to fires, especially in cases of severe or high-intensity fires. The wildfires of the year 2007, which were connected to exceptional drought and heatwaves, have revealed this clearly. Moreover, the droughtrelated process framework of fir dieback presents a threat to the existence of fir forests in Greece. Eventually, the regressive timberline dynamics are an indication that in recent decades drought has caused the decay of older firs and also prevented regeneration on dry, rocky sites. All this fits to the expectation that climatically induced effects on vegetation will become visible first at the ecological boundary of a certain species (i.e. at the margin of geographical distribution or at ecotones).

Yet, we must be careful to assign these observations readily as the fingerprints of climate change. Information from dendrochronology and historical archives leave no doubt that severe drought events and dry periods have been characteristic of the climate in Greece for many centuries. This makes it highly likely that fir dieback (in relation with bark beetle outbreaks) is a completely natural phenomenon in the mountain forests of the Hellenic peninsula, not just occurring since the $20^{\text {th }}$ century.

Also, devastating wildfires are to be evaluated in a careful way. There is no doubt that heat waves and lack of rain play a major role in the occurrence of forest fires, but it is wrong to hold climate (change) alone responsible. Two other factors, the accumulation of fuel (caused by land abandonment) and the source of ignition (mainly caused by human impact, often by arson), have to be highly considered. Since both can be controlled by forest management these two factors should be in the focus of actions aiming at the protection of mountain forests.

Nevertheless, there is no doubt that climatic changes, by causing a generally more arid climate in Greece or only by increasing the frequency of extreme heat events, would exacerbate the occurrence of bark beetle outbreaks and fir dieback as well as the risk for devastating wildfires. Since several climate studies expect such a scenario, it will be the task for forest managers to take preventive steps in order to protect the oromediterranean fir/black pine forests, which are highly vulnerable to negative climate change impacts.

Since fire suppression and reforestation have proven to be difficult and expensive tasks (often with very disappointing results), more promising steps should be of first order, such as: education of the population, fuel management, blocking the access to forests during heat waves, and the establishment of a small-scale mosaic cycle by active forest management. Scientific studies on patch dynamics and regeneration mechanisms in the Greek mountain forests should accompany these efforts to enlarge the scientific basis. Moreover, fixed plots for long-term monitoring should be installed to gain more knowledge about the vegetation dynamics inside the forests and on fire sites.

\section{Author Contributions}

RB conceived the review article. It is based on field measurements, data processing and statistical analysis performed by $R B$ and $A C$. RB and $A C$ wrote the manuscript.

\section{Funding}

This research received no external funding.

\section{Acknowledgments}

The authors would like to thank the Greek forest authorities and especially Dr. Panos Tsopelas for their support during various periods of field work. Additional thanks to two anonymous reviewers for their valuable comments, which greatly improved the manuscript.

\section{Conflicts of Interest}

The authors declare no conflict of interest.

\section{REFERENCES}

Arianoutsou M, Christopoulou A, Kazanis D, Tountas Th, Ganou E, Bazos I, Kokkoris I, 2010. Effects of fire on high altitude coniferous forests of Greece. In: Viegas DX (eds) Proceedings of the "VI International Conference on Forest Fire Research", Coimbra, Portugal, pp. 12.

Aussenac G, 2002. Ecology and ecophysiology of circumMediterrean firs in the context of climate change. Ann For Sci 59(8): 823-832. https://doi.org/10.1051/forest:2002080.

Avtzis N, 1983. Das Auftreten von Thaumetopoea pityocampa Schiff. in Griechenland. Dasiki Erevna 4: 137-144. (in Greek with German summary).

Barbu C, 2010. The incidence and distribution of white mistletoe (Viscum album ssp. abietis) on Silver fir (Abies alba Mill.) stands from Eastern Carpathians. Ann For Res 53(1): 27-36.
Block M, Brandes R, 2001. Dynamik und Strukturwandel mediterraner Tannenwälder in Südspanien und Südgriechenland. Mitteilungen der Fränkischen Geographischen Gesellschaft 48: 305-335. http://fggerlangen.de/fgg/ojs/index.php/mfgg/article/view/99/86.

Bolle H-J (ed), 2003. Mediterranean Climate. Variability and Trends. Springer-Verlag Berlin Heidelberg, Berlin, Germany, 371 p. https://doi.org/10.1007/978-3-642-55657-9.

Brandes R, 2007. Waldgrenzen griechischer Hochgebirge. Unter besonderer Berücksichtigung des Taygetos, Südpeloponnes (Walddynamik, Tannensterben, Dendrochronologie). PhD Thesis, University Erlangen-Nuernberg, Germany - Erlanger Geographische Arbeiten, Sonderband 36. http://nbnresolving.de/urn:nbn:de:bvb:29-opus-5410. 
Brandes R, 2008. Wald und Waldbrände in Griechenland - Eine Betrachtung aus vegetationsgeographischer Sicht. Hellenika NF 3: 70-90.

Brandes R, 2009. Dendrochronology on Pinus nigra in the Taygetos mountains, southern Peloponnisos. In: Manning, SW, Bruce MJ (eds) Tree-rings, Kings, and Old World Archaeology and Environment (Papers presented in honor of Peter lan Kuniholm). Oxford, UK, pp. 81-95.

Brandes $R$, Ise $M, 2007$. Fingerprints of climate change in Mediterranean mountain forests? - Observations on Mediterranean fir species threatened by climate change. GeoÖko 28: 1-26.

Brofas G, Economidou E, 1994. Le dépérissement de Sapin du Mont Parnasse (Grèce). Le rôle des conditions climatiques et écologiques. Ecologia Mediterranea 20(1/2): 1-8.

Brunner I, Herzog C, Dawes MA, Arend A, Sperisen C, 2015. How trees respond to drought. Front Plant Sci 6: 547. https://doi. org/10.3389/fpls.2015.00547.

Bunn A, Korpela M, Biondi F, Campelo F, Mérian P, Qeadan F, Zang C, 2019. dpIR: Dendrochronology Program Library in R. R package version 1.7.0. https://CRAN.R-project.org/ package $=$ dplR.

Christopoulou A, Fulé PZ, Andriopoulos P, Sarris D, Arianoutsou $M, 2013$. Dendrochronology-based fire history of Pinus nigra forest in Mount Taygetos, Southern Greece. For. Ecol. Manag. 293: 132-139. https://doi.org/10.1016/i.foreco.2012.12.048.

Christopoulou A, Fyllas N, Andriopoulos P, Koutsias $\mathrm{N}$, Dimitrakopoulos P, Arianoutsou M, 2014. Post-fire regeneration patterns of Pinus nigra in a recently burned area in Mount Taygetos, Southern Greece: the role of unburned forest patches. For Ecol Manag 327: 148-156. https://doi. org/10.1016/i.foreco.2014.05.006.

Christopoulou A, Kazanis D, Fyllas NM, Arianoutsou M, 2018. Post-fire recovery of Abies cephalonica forest communities: the case of Parnitha National Park, Attica, Greece. iForest 11: 757-764. https://doi.org/10.3832/ifor2744-011.

Christopoulou A, Mallinis G, Vassilakis E, Farangitakis G-P, Fyllas NM, Kokkoris G, Arianoutsou M, 2019. Assessing the impact of different landscape features on post-fire forest recovery with multi-temporal remote sensing data: the case of Mount Taygetos (southern Greece). Int J Wildland Fire 28(7): 521-532. https://doi.org/10.1071/WF18153.

Delcourt PA, Delcourt HR, 1992. Ecotone Dynamics in Space and Time. In: Hansen AJ, Di Castri F, (eds) Landscape boundaries - Consequences for Biotic Diversity and Ecological Flows. (=Ecological studies, Vol. 92). New York, USA, pp. 19-54.

Diffenbaugh NS, Giorgi F, 2012. Climate change hotspots in the CMIP5 global climate model ensamble. Climatic Change 114: 813-822. https://doi.org/10.1007/s10584-012-0570-x.

Dury M, Hambuckers A, Warnant P, Henrot A, Favre E, Oberdous $M$, Francois L, 2011. Responses of European forest ecosystems to 21st century climate: assessing changes in interannual variability and fire intensity. iForests 4(2): 82-99. https://doi. org/10.3832/ifor0572-004.

Efthimiou G, Detsis V, Theodoropoulos O, 2014. Post fire restoration in a National Park: the Parnitha case, Greece. Proceedings of the 12th International Conference on Protection and Restoration of the Environment (Pre12), June 29 to July 03, 2014, Skiathos Island, Greece. pp. 408-413.

Fischer EM, Schar C, 2010. Consistent geographical patterns of changes in high-impact European heatwaves. Nat Geosci 3: 398-403. https://doi.org/10.1038/ngeo866.

Fritts HC, 1976. Tree rings and climate. Academic Press, New York, USA, 582 p. https://doi.org/10.1016/B978-0-12-2684500.X5001-0.

Fulé $P Z$, Ribas $M$, Gutiérrez E, Vallejo R, Kaye MW, 2008. Forest structure and fire history in an old Pinus nigra forest eastern Spain. For Ecol Manag 255(3-4): 1234-1242. https://doi. org/10.1016/i.foreco.2007.10.046.
Fyllas NM, Christopoulou A, Galanidis A, Michelaki CZ, Giannakopoulos C, Dimitrakopoulos PG, Fulé PZ, Arianoutsou $M, 2017$. Tree growth-climate relationships in a forest-plot network on Mediterranean mountains. Sci Total Environ 598: 393-403. https://doi.org/10.1016/j.scitotenv.2017.04.145.

Ganatsas P, Daskalakou E, Paitaridou D, 2012. First results on early post-fire succession in an Abies cephalonica forst (Parnitha National Park, Greece). iForest 5(1): 6-12. doi https://doi. org/10.3832/ifor0600-008.

Gao XJ, Giorgi F, 2008. Increased aridity in the Mediterranean region under greenhouse gas forcing estimated from high resolution simulations with a regional climate model. Global Planet Change 62(3-4): 195-209. https://doi.org/10.1016/j. gloplacha.2008.02.002.

Gates DM, 1993. Climate change and its biological consequences. Sinauer Associates Inc Sunderland, Massachusetts, USA, 280 p.

Giannakopoulos C, Le Sager P, Bindi M, Moriondo M, Kostopoulou E, Goodess CM, 2009. Climatic changes and associated impacts in the Mediterranean resulting from a $2^{\circ} \mathrm{C}$ global warming. Global Planet Change 68(3): 209-224. https://doi. org/10.1016/i.gloplacha.2009.06.001.

Giorgi F, Lionello P, 2008. Climate change projections for the Mediterranean region. Global Planet Change 63(2-3): 90-104. https://doi.org/10.1016/i.gloplacha.2007.09.005.

Glaser R, Beck C, Beyer U, 2000. Vom mittelalterlichen Wärmeoptimum über die Kleine Eiszeit ins modern Treibhausklima. Peterm. Geogr Mitt 144(4): 44-53.

Grove JM, Conterio A, 1995. The climate of Crete in the sixteenth and seventeenth centuries. Climatic Change 30: 223-247. https://doi.org/10.1007/BF01091843.

Grove JM, Grove AT, 1992. Little Ice Age climate in the Eastern Mediterranean. In: Frenzel B (ed) Palaeoclimate Research (Vol 7) - European climate reconstructed from documentary data: methods and results. Stuttgart, Germany, pp.45-50.

Harrington TC, 1993. Biology and taxonomy of fungi associated with bark beetles. In: Schowalter TD, Filip GM (eds) Beetlepathogen interactions in conifer forests. Academic Press, Harcourt Brace \& Co., London, UK, pp. 37-58.

Hempel L, 1990. Stürmische Nordwinde im östlichen Mittelmeer innerhalb des Systems der "Grosswetterlagen" Europas. Geoökodynamik 20: 323-341.

Hempel L, 2000. Stürmische Nordwinde im östlichen Mittelmeer innerhalb des Systems der "Grosswetterlagen" Europas. Geoökodynamik 21: 285-303.

Holtmeier FK, 2003. Mountain Timberlines. Ecology, Patchiness and Dynamics (Advances in Global Change Research). Springer Netherlands, Dordrecht, The Netherlands. https://doi. org/10.1007/978-1-4020-9705-8.

Horvat I, Glavac V, Ellenberg H, 1974. Vegetation Südosteuropas. Stuttgart, Germany.

Hughes MK, Kuniholm PI, Eischeid J, Garfin GM, Griggs CB, Latini C, 2001. Aegean tree-ring signature years explained. Tree-Ring Res 57(1): 67-73.

Jacquet OJ, 2012. Defoliation by processionary moth significantly reduces tree growth: a quantitative review. Ann For Sci 69(8): 857-866. https://doi.org/10.1007/s13595-012-0209-0.

Kailidis D, Markalas S, 1988. Dürreperioden in Zusammenhang mit sekundärem Absterben und Massenvermehrungen rindenbrütender Insekten in den Wäldern Griechenlands. Anz. Schädlingskunde, Pflanzenschutz, Umweltschutz 61: 25-30.

Klippel L, Krusic PJ, Brandes R, Hartl C, Belmecheri S, Dienst M, Esper J, 2018. A 1286-year hydro-climate reconstruction for the Balkan Peninsula. Boreas 47(4): 1218-1229. https://doi. org/10.1111/bor.12320.

Korakis G, 2015. Forest Botany. (in Greek). 
Koutsias N, Arianoutsou M, Kallimanis AS, Mallinis G, Halley JM, Dimopoulos P, 2012. Where did the fires burn in Peloponnisos, Greece the summer of 2007? Evidence for a synergy of fuel and weather. Agr Forest Meteorol 156: 41-53. https://doi. org/10.1016/j.agrformet.2011.12.006.

Kuniholm PI, 1990. Archaeological evidence and non-evidence for climatic change. Phil Trans R Soc Lond A 330: 645-655.

Lamb HH, 1977. Climate : present, past and future, Volume 2: Climatic history and the future. Methuen, London, UK, $835 \mathrm{p}$.

Larsen JB, Yang W, Tiedemann A, 1990. Effects of ozone on gas exchange, frost resistance, flushing and growth of different provenances of European silver fir (Abies alba Mill). Eur J Forest Pathol 20 (4): 211-218. https://doi. org/10.1111/j.1439-0329.1990.tb01132.x.

Lelieveld J, Berresheim H, Borrmann S, 2002. Global Air Pollution Crossroads over the Mediterranean. Science 298: 794-799. https://doi.org/10.1126/science.1075457.

Lelieveld J, Hadjinicolaou P, Kostopoulou E, Chenoweth J, El Maayar M, Giannakopoulos C, Hannides C, Lange MA, Tanarhte $\mathrm{M}$, Tyrlis $\mathrm{E}$, Xoplaki E, 2012. Climate change and impacts in the Eastern Mediterranean and Middle East. Climatic Change 114: 667-687. https://doi.org/10.1007/s10584-012-0418-4.

Lindner M, Fitzgerald JB, Zimmermann NE, Reyer C, Delzon S, Van Der Maaten E, Schelhaas MJ, Lasch P, Eggers J, Van Der Maaten-Theunissen M, Suckow F, Psomas A, Poulter B, Hanewinkel M, 2014. Climate change and European forests: what do we know, what are the uncertainties, and what are the implications for forest management? I Environ Manag 146: 69-83. https://doi.org/10.1016/i.jenvman.2014.07.030.

Lindner M, Maroschek M, Netherer S, Kremer A, Barbati A, Garcia-Gonzalo J, Seidl R, Delzon S, Corona P, Kolström M, Lexer MJ, Marchetti M, 2010. Climate change impacts, adaptive capacity, and vulnerability of European forest ecosystems. For Ecol Manag 259: 698-709. https://doi.org/10.1016/i. foreco.2009.09.023.

Markalas S, 1987. Der Befall von (auf Terrassen angelegten) Kiefernaufforstungen durch den Prozessionsspinner (Thaumetopoea pityocampa Schiff.). Forstarchiv 5: 205-207.

Markalas S, 1992. Site and stand factors related to mortality rate in a fir forest after combined incidence of drought and insect attack. For Ecol Manag 47(1-4): 367-374. https://doi. org/10.1016/0378-1127(92)90286-।.

Mayer H, 1985. Wälder Europas. Stuttgart, Germany.

McNeill JR, 1992. The mountains of the Mediterranean world: an environmental history. Cambridge University Press, UK, 448 p. https://doi.org/10.1017/CBO9780511529023.

Meiggs R, 1982. Trees and timber in the ancient Mediterranean world. Clarendon Press, Oxford, UK, 553 p.

Mitsopoulos I, Raftoyannis Y, Bakaloudis D, 2015. Climate change, wildfires and fir forests in Greece: perceptions of forest managers. South-east Eur for 6(2): 143-157. https://doi. org/10.15177/seefor.15-12.

Nastos PT, Kapsomenakis J, 2015. Regional climate models simulations of extreme air temperature in Greece. Abnormal or common records in the future climate? Atmos Res 152: 4360. https://doi.org/10.1016/i.atmosres.2014.02.005.

Paine TD, Baker FA, 1993. Abiotic and biotic predisposition. In: Schowalter TD, Filip GM (eds) Beetle-pathogen interactions in conifer forests. Academic Press, Harcourt Brace \& Co., London, UK, pp.61-79.

Papadopoulos A, 2016. Tree ring patterns and climate response of Mediterranean fir populations in Central Greece. Dendrochronologia 40: 17-25.

Peters RL, 1990. Effects of global warming on forests. For Ecol Manag 35(1-2): 13-33. https://doi.org/10.1016/03781127(90)90229-5.

Pickett S, White P (eds) 1985. The Ecology of Natural Disturbance and Patch Dynamics. Academic Press, Orlando, USA, 472 p. https://doi.org/10.1016/C2009-0-02952-3.
Politi PI, Arianoutsou M, Stamou GP, 2009. Patterns of Abies cephalonica seedling recruitment in Mount Aenos National Park, Cephalonia, Greece. For Ecol Manag 258: 1120-1136. https://doi.org/10.1016/i.foreco.2009.05.038.

Quézel P, 1977. Forests of the Mediterranean Basin. In UNESCO (eds) Mediterranean forests and maquis: ecology, conservation and management (= MAB technical notes 2 ).

Raftoyannis Y, Spanos I, 2015. Regeneration of Abies cephalonica Loudon after a Large Fire in Central Greece. South-east Eur for 6(1): 1-10. https://doi.org/10.15177/seefor.15-04.

Remmert H, 1991. The Mosaic.Cycle Concept of Ecosystems - An Overview. In: Remmert H (ed) The Mosaic-Cycle Concept of Ecosystems. Ecological Studies 85. Springer, Berlin, Heidelberg, Germany. https://doi.org/10.1007/978-3-642-75650-4 1.

Richter K, Eckstein D, 1990. A proxy summer rainfall record for southeastern Spain derived from living and historic pine trees. Dendrochronologia 8: 67-82.

San-Miguel-Ayanz J, Moreno JM, Camia A, 2013. Analysis of large fires in European Mediterranean landscapes: lessons learned and perspectives. For Ecol Manag 294: 11-22. https://doi. org/10.1016/j.foreco.2012.10.050.

Sarris D, Christopoulou A, Angelonidi E, Koutsias N, Fulé Pz, Arianoutsou M, 2014. Increasing extremes of heat and drought associated with recent severe wildfires in southern Greece. Reg Environ Change 14:1257-1268. https://doi. org/10.1007/s10113-013-0568-6.

Schütt P, 1994. Tannenarten Europas und Kleinasiens. Landsberg a. Lech, Germany.

Schweingruber FH, 1988. Tree rings. Basics and Applications of Dendrochronology. Springer Netherlands, 276 p. https://doi. org/10.1007/978-94-009-1273-1.

Sinclair WA, Lyon HH, Johnson WT, 1987. Diseases of trees and shrubs. Cornell University Press, Ithaca, USA, $574 \mathrm{p}$.

Siorokou S, Detsis V, Efthimiou G, 2015. A preliminary assessment of the use of black pine in the reforestation of Mount Parnitha National Park, Greece. Ecology \& Safety 9: 171-176.

Smidla H, Tkaczyk M, Plewa R, Tarwacki G, Sierota Z, 2019. Impact of common mistletoe (Viscum album L.) on Scots pine forestsA call for action. Forests 10(19): 847. https://doi.org/10.3390/ f10100847.

Tapias R, Climent J, Pardos JA, Gil L, 2004. Life histories of Mediterranean pines. Plant Ecol 171: 53-68. https://doi. org/10.1023/B:VEGE.0000029383.72609.f0.

Thirgood JV, 1981. Man and the Mediterranean Forest. Academic Press, London, UK, $194 \mathrm{p}$.

Tsagari K, Karetsos G, Proutsos N, 2011. Forest fires in Greece, 1983-2008. WWF Greece and ETHIAGE-IMDO \& TDP, 112 p. (in Greek).

Tsopelas P, 1999. Distribution and ecology of Armillaria species in Greece. Eur. J. Forest Pathol 29(2): 103-116. https://doi. org/10.1046/i.1439-0329.1999.00139.x.

Tsopelas P, Angelopoulos A, Economou A, Soulioti N, 2004. Mistletoe (Viscum album) in the fir forests of Mt. Parnis, Greece. For Ecol Manag 202(1-3): 59-65. https://doi. org/10.1016/i.foreco.2004.06.032.

Tsopelas P, Korhonen K, 1996. Hosts and distribution of the intersterility groups of Heterobasidion annosum in the highlands of Greece. Eur J Forest Pathol 26(1): 4-11. https:// doi.org/10.1111/i.1439-0329.1996.tb00705.x.

Vitali A, Garbarino M, Camarero JJ, Malandra F, Toromani E, Spalevic V, Curovic M, Urbinati C, 2019. Pine recolonization dynamics in Mediterranean human-disturbed treeline ecotones. For Ecol Manag 435: 28-37. https://doi. org/10.1016/i.foreco.2018.12.039.

Waldner PO, Schweingruber FH, 1996. Temperature influence on decennial tree-ring width and density fluctuations of subalpine and boreal conifers in Western Europe since 1850 A.D. Dendrochronologia 14: 127-151. 
Walker BH, 1991. Ecological consequences of atmospheric and climate change. Climatic Change 18: 301-316. https://doi. org/10.1007/BF00139003.

Walther GR, 2001. Adapted behavior and shifting ranges of species - a result of recent climate warming? In: Walther G-R, Burga CA, Edwards PJ (eds) "Fingerprints" of Climate Change. Adapted behavior and shifting species ranges. Springer, Boston, MA, USA. https://doi.org/10.1007/978-1-4419-869241.

Woodward S, Stenlid J, Karjalainen R, Hüttermann A (eds) 1998. Heterobasidion annosum: Biology, Ecology, Impact and Control. CABI Publishing, Cambridge, UK, 608 p.
Xoplaki E, Maheras P, Luterbacher J, 2001. Variability of climate in Meridional Balkans during the periods 1675-1715 and 17801830 and its impact on human life. Climatic Change 48: 581615. https://doi.org/10.1023/A:1005616424463.

Yousefpour R, Temperli C, Jacobsen JB, Thorsen BJ, Meilby $H$, Lexer MJ, Lindner M, Bugmann H, Borges JG, Palma JHN, Ray D, Zimmermann NE, Delzon S, Kremer A, Kramer K, Reyer CPO, Lasch-Born P, Garcia-Gonzalo J, Hanewinkel M, 2017. A framework for modeling adaptive forest management and decision making under climate change. Ecol Soc 22(4):40. https://doi.org/10.5751/ES-09614-220440. 